\title{
Documents and cif contracts
}

\author{
by Professor M G Bridge
}

\begin{abstract}
Professor Bridge explores a number of questions relating to cost insurance and freight contracts, in particular the problems arising from the separation of rights in relation to goods from rights in relation to documents and what is meant by a 'conforming' contract.
\end{abstract}

I $t$ is well-established that a cif buyer has separate rights in respect of the documents and of the goods, and that the transfer of documents from seller to buyer precedes any rights that the buyer may have in respect of the goods. Hence, a forthcoming complaint about the goods cannot be visited upon unoffending documents that conform to the contract. But what does 'conforming' mean? Does it mean that documents need only outwardly show that the cif seller has complied with its obligations? Or that the information they contain must be accurate? In answering these questions, a further question demands consideration: whether a conforming document has the same meaning under a cif contract as it has for a letter of credit contract.

\section{THE NATURE OF CIF CONTRACTS}

It is often said of cif contracts that they are documentary sales. A series of cases prompted by shipping losses in the Great War questioned whether cif contracts were sales of goods at all or rather sales of documents. The firm answer given was that they were sales of goods performed through the medium of documents. Earlier, the House of Lords, in the famous case of Couturier v Hastie (1856) HLC 673, had made the same point in concluding that a tender of cif documents did not, on the construction of the contract, activate the buyer's duty to pay when those documents concerned goods that had ceased to exist at the contract date. The contract presupposed the existence of those goods.

Although a sale of goods contract, the character of a cif contract as a documentary sale is such that the seller's physical duties are suspended until the documentary transfer has been completed. What are these duties? A cif seller never becomes bound to deliver the goods to the buyer or to an agent of the buyer. Instead, the conventional duty under the Sale of Goods Act 1979 ('SGA') s. 27 of a seller to deliver, is commuted under the cif contract into duties to ship, or procure or adopt the shipment of, conforming goods and to transfer documents that give the buyer direct rights against the insurer and the carrier. Subject to the terms of the contract, the seller's physical duties lie in the description, quality and fitness of the goods shipped, as well as in their timely shipment. At the earliest, these obligations spring upon completion of the documentary transfer.

Between the shipment of the goods and the documentary transfer, modern bulk commodities contracts impose on the seller a duty to issue a notice of appropriation. This assures the buyer of forthcoming performance and defines the documents that the seller will later transfer to the buyer. It stitches together the physical and documentary parts of the seller's performance. This is why the seller's physical duties can accurately be said to
They cannot plausibly be said to come into existence only on that event.

\section{COMMERCIAL RISK}

Cash on delivery of documents is a characteristic feature of cif sales. The consequence of the seller's physical duties being suspended is that the paying buyer is compelled to accept a commercial risk - the risk of pursuing the seller - after the documentary transfer, to recover the price when terminating the contract for a discharging physical breach by the seller. This risk can have insolvency dimensions. As is clear from Kwei Tek Chao $v$ British Traders \& Shippers Ltd (1954) 2 QB 459, the property in rejected goods revests in the seller and the buyer does not have a lien over them for the return of the price.

In a conventional domestic sale, the buyer does not have to pay for goods unseen but, under the SGA 1979 s. 34, may insist on first examining them. This gives the buyer some protection against the commercial risk borne by the cif buyer. In a cif contract, in order to give effect to the buyer's assumption of the commercial risk that arises from paying against documents, this pre-payment examination is excluded. The rule that a cif buyer first has to pay against conforming documents before pursuing the seller to recover the price when the goods are rejected, has been criticised by R M Goode in Commercial Law for its lack of 'commercial realism' but, if the purpose of the rule is to persuade a buyer to think twice before exercising technical rights of termination, then it may not be lacking in realism at all.

In E Clemens Horst Ltd v Biddell Brothers (1911) $1 \mathrm{~KB} 934$, the buyers of a cif cargo of hops shipped in San Francisco declined to pay upon the documentary tender, insisting that they first had the right to examine the goods to see that they conformed to the contract. If the buyers' contention had been sound, the sellers would have had the invidious choice of taking responsibility for the landing and warehousing of the goods (at their own expense), or of surrendering the bill of lading so that the buyer could carry out the examination, in which case they would lose the security that goes with retaining the bill of lading. In both cases, the cif buyer's commercial risk would thereby be overturned, at least to the extent of any defects in the hops coming to light in the course of the buyers' examination. Consequently, the decision of the House of Lords that a cif buyer has no right to examine the goods before payment, has an air of inevitability about it.

\section{DOCUMENTARY TENDER}

A cif buyer, prevented from examining beforc payment, may still be unwilling to accept the commercial risk of pursuing the seller to recover the price if and when the goods prove to be non-conforming. May the buyer anticipate a future breach of contract regarding the physical condition of the goods and 
refuse a tender of documents that on their face are perfectly regular? This point arose in Gill \& Duffus SA v Berger \& Co Inc [1984] AC 382, where the buyers declined to pay against a tender of shipping documents that did not include a report, issued by an inspection agency at the port of discharge, confirming that the quality of the out-turned goods matched a sample previously taken. By the time the case reached the House of Lords, the buyers had abandoned their contention that the sellers' documentary tender should have included this certificate. In Lord Diplock's words:

[A] certificate ... as to the quality of the goods at port of discharge is not, and indeed is incapable of being, included among shipping documents which a [cif] seller is required to tender to his buyer ...'

Although it is a fact of modern commercial life that goods commonly arrive at the port of discharge before the shipping documents can be tendered to the buyer, the cif seller should not have to present the bill of lading to the ship to facilitate the inspection of the cargo that would lead to the issue of the quality certificate. Furthermore, so well known is the cif seller's duty to tender the trio of bill of lading, insurance policy and invoice, that any addition to that documentary package should need to be spelt out in the contract. A simple reference to payment against documents ought not in itself to suffice.

In the House of Lords, the buyers were treated as having unlawfully repudiated the contract when refusing the documentary tender. When the sellers accepted the buyers' repudiation, they 'ceased to be under any contractual obligation to deliver (sic)' the goods. More accurately, their physical duties did not spring. As Lord Diplock phrased the matter, the buyers' right to reject the goods, if it existed at all, would:

'not become exercisable until the seller['s] ... reservation of the right of disposal ... is terminated by his transferring the shipping documents to the buyers'.

In the event it was settled that the buyers would never have acquired the right to reject the goods. This was because of the contractually binding character of the quality certificate which showed due compliance by the sellers with the contract.

Nevertheless, the court considered what the position would have been had the buyers had a claim against the sellers for breach of their physical obligations. The sellers had terminated the contract for the buyers' repudiatory breach and were prima facie entitled, in the usual way, to damages representing the difference between the contract price and the (lower) market price prevailing when the sellers accepted the buyers' repudiation. The court nevertheless asserted that the sellers' damages should be discounted to the extent of any cross claim for breach of warranty that the buyers would have been entitled 'to set up in diminution of the contract price'. This formulation of the matter does not quite go far enough. In principle, there is every reason to discount the sellers' damages to nominal proportions if the buyers would have gone on lawfully to reject the goods and bring an action for the recovery of the price.

\section{DILUTION OF RISK}

However the buyers' position is described, the most striking feature of Gill \& Duffus is that it countenances the dilution of the cif buyer's commercial risk. Following the rule in British and Benington's Ltd v North Western Cachar Tea Co Ltd [1923] AC 48, a cif buyer who anticipates a future physical breach is denied the normal right of a contracting party entitled to terminate for no stated reason, or for the wrong stated reason, provided that good grounds for the termination, whether known or not, existed at the time that party did terminate the contract. Nevertheless, that buyer, if sure of his position, can take a calculated risk and repudiate the contract. If the seller's net claim is likely to be modest or even nominal, then litigation ought not to be a likely prospect. In substance if not in name, that cif buyer would be able to bring forward the consequent right to reject the goods and exercise it notwithstanding the tender of conforming documents. This undermines the fundamental rule asserted in Gill \& Duffus.

And yet, since the function of contract damages is to put the plaintiff in the position that he would have occupied if no breach of contract had been committed, principle demands that account be taken of the fact that a seller, condemned to a future physical breach, is in a very precarious position at the point of tender and triggers his own breach by the very act of transferring the shipping documents. The commercial integrity of the cif contract stops short of offending fundamental principles of damages assessment.

If the result is unpalatable and threatening to the documentary transfer, then the contract forms should be amended. One possibility would be for the form expressly to allow the seller to claim damages for non-acceptance of documents without an allowance being made for the buyer's cross claim. The danger here is that such a provision would be struck down as a penalty. Alternatively, the contract could simply exclude any liability in respect of physical breaches, unless and until the documentary transfer is duly completed. An exemption clause of this kind in an international sale contract would be subject to few controls.

\section{NON-CONFORMING DOCUMENTS}

There may be a more dangerous threat to the documentary character of the cif contract than that revealed in Gill \& Duffus. It arises out of the meaning of non-conforming documents. We can say that a non-conforming document includes, for example, a bill of lading that reveals a physical breach, such as a shipment on 1 August when the contract calls for a July shipment. But suppose that bill of lading recites a shipment date of 31 July when in fact the shipment occurred on 1 August. On its face, the bill of lading is a conforming document, but it states an untruth. Is the cif buyer bound to accept it?

It is instructive to refer to a decision of the Australian High Court that was treated in dismissive terms by Lord Diplock in Gill \& Duffus as:

'one of those submerged cases which lawyers in general have tacitly accepted as being a total loss, until it was dredged up in the course of the hearing of the instant case'.

That decision is Henry Dean \& Sons (Sydney) Pty Ltd v O'Day Pty Ltd (1927) 39 CLR 330, more particularly the judgments off Knox CJ and Higgins J. As their judgments were explained in Gill \& Duffus, they sanctioned the rejection of:

'conforming shipping documents if it should subsequently turn out that the actual goods shipped under the conforming documents did not in fact conform to the contract'.

This may be true of Higgins J but it is worth considering what Knox CJ in fact did say. 
Henry Dean concerned a cif contract for the sale of 'Liverpool wheat sacks'. The buyers refused the sellers' draft bill of exchange on the ground that the goods shipped were not Liverpool wheat sacks. The question was whether the sellers at the time of tender were ready and willing to perform. This is more than merely a matter of unreformed New South Wales civil procedure; it goes to the heart of a contracting party's right to call upon the other to perform when the former's duty is precedent to or concurrent with the latter's duty. It was the view of Knox CJ that the buyer was bound only to take up 'proper shipping documents', which were documents concerning goods 'of the description contained in the contract which have been shipped'. In other words, the documents were not conforming if they misdescribed the goods.

\section{TIMING ERRORS}

If this is a sound approach, there is no reason to confine it to matters of description. It could apply too in cases where the bill of lading falsely attests to the shipment of the goods in apparent good order and condition and where the bill falsely states the shipment date. An examination of English case law in the area of shipment dates shows support for Knox CJ's position.

In Proctor \& Gamble Philippine Mfg Corpn v Kurt A Becher GmbH \& Co (1988) $2 \mathrm{Ll}$ Rep 21, the sellers conceded the buyers' right to reject a bill of lading wrongly showing a timely shipment. This concession came at no cost since, though the bill of lading was wrongly dated, there had been a shipment within the contract period and the buyer had accepted the documents. But Kerr LJ stated in clear terms that the seller impliedly guarantees that the documents are 'true in all material respects'. Similarly, in United Baltic Corpn v Burgett \& Newsam (1921) 8 Ll L Rep 190, Bankes LJ recognised the right of a buyer under a contract permitting shipment in either January or February, to reject a bill recording a January shipment, when in fact the shipment occurred in February.

At first instance in Proctor \& Gamble, however, Leggatt J stated that the buyers were bound to take up documents regular on their face. Nevertheless, he cited two exceptions: where the sellers had committed fraud and where there existed sufficient evidence that the bill of lading was wrongly dated. As for the latter, Knox CJ in Henry Day had been clear that a buyer could reject documents, even though lacking proof at the time of tender that they contained untrue statements. The buyer was entitled to take the risk of later vindication. If Leggatt J meant that the evidence had to exist at the time of tender this will be a difficult test to apply at a remote subsequent date when the matter is being litigated or arbitrated. Yet it coincides with a provision in the Grain and Feed Trade Association (GAFTA) contracts that the:

'[d]ate of the Bill(s) of Lading shall be accepted as proof of the date of shipment in the absence of evidence to the contrary'

and the contract in Proctor \& Gamble incorporated the terms in the GAFTA 100 contract (which is the leading cif standard form contract). It may be that Leggatt J's remarks were addressed to the buyers' position under the GAFTA 100 contract and not at common law:

Subject to contrary provision in the contract, it is submitted that the documents tendered by the cif seller have to be true in all material respects. As for what 'material respects' are, it is submitted that a misstatement is material if the documents could have been rejected had they contained the equivalent true statement. A bill of lading attesting to the shipment of the goods in good order and condition when this is in fact not the case, may be rejected, since a bill claused to show the true condition of the goods could lawfully be rejected by the buyer. Again, to revert to the example of the contract for the July shipment, a bill of lading falsely recording a 31 July shipment may be rejected because a truly dated bill of lading, showing shipment on 1 August, could be rejected for non-conformity with the contract. Going further, the date of shipment itself is material in that a bill of lading falsely recording the shipment date can be rejected, even if the shipment in fact occurred within the shipment period.

\section{LETTER OF CREDIT COMPLICATIONS}

If this statement of the law on the meaning of 'conforming documents' is correct, then a coach and four has been run through the decision of the House of Lords in Gill \& Duffus that a cif buyer may not, at the time of documentary tender, invoke the doctrine of anticipatory repudiation and pray in aid the seller's future physical breach (presumably, even where the documents render this unavoidable) to justify the rejection of the shipping documents. Lord Diplock in Gill \& Duffus castigated as 'wrong' the dissenting judgment of Robert Goff LJ in the Court of Appeal that the buyer at the documentary stage could anticipate his future right to reject the goods themselves. But in Commercial Law, R M Goode subjects Lord Diplock's view, in turn, to stringent criticism. By alternative means stated above, the views of Robert Goff LJ would appear to be supportable.

Nevertheless, there is the letter of credit case of United City Merchants (Investments) Ltd v Royal Bank of Canada (1983) 1 AC 168 to consider. In that decision, the House of Lords ruled that a confirming bank was bound to accept shipping documents tendered pursuant to a letter of credit, notwithstanding the fact that the bill of lading had been falsely dated, not by the beneficiary of the letter of credit, but by loading brokers acting for the carrier. In the absence of fraud, the bank was bound to pay. There was no defence to the claim on the ground that the documents stated some material fact that was inaccurate. The bank was bound to pay against apparently conforming documents.

United City Merchants has been roundly condemned for a number of misconceptions concerning letters of credit, including the one above. Since the case does not lay down the law on sale of goods, it can, subject to one point, be disregarded for present purposes. At the heart of the decision lies the concern that 'the whole system of financing international trade by documentary means' should not be undermined. This is far from the bilateral position of seller and buyer under a cif contract. In commodity sales, the standard forms require cash against documents and do not stipulate for the opening of a letter of credit. But if payment by letter of credit were introduced in such contracts, the effect would be to vary what would otherwise be the position under the contract of sale. Apart from this one point, the position on letters of credit should not infiltrate the law of sale.

Professor M G Bridge

University of Nottingham 